\title{
RELIABILITY OF IP TUNNELS \\ IN MILITARY NETWORKS
}

\section{NIEZAWODNOŚĆ TUNELI IP}

W SIECIACH MILITARNYCH

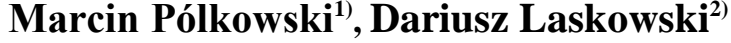 \\ 1) Transbit Sp. z o.o.., \\ ${ }^{2)}$ Wojskowa Akademia Techniczna im. J. Dąbrowskiego \\ e-mail:dariusz.laskowski@wat.edu.pl
}

\begin{abstract}
The military networks, contrary to commercial ones, require standards which provide the highest level of security and reliability. The process to assuring redundancy of the main connections through applying various protocols and transmission media causes problem with time needed to re-establish virtual tunnels between different locations in case of damaged link. This article compares reliability of different IP (Internet Protocol) tunnels, which were implemented on military network devices.
\end{abstract}

Keywords: reliability, IP, tunneling

Streszczenie: $W$ odróżnieniu od cywilnych rozwiązań teleinformatycznych sieci militarne wymagaja standardów zapewniajacych zarówno najwyższego poziomu bezpieczeństwo jak $i$ najwyższa możliwa niezawodność. Zapewnianie redundancji najważniejszych połaczeń poprzez zastosowanie różnych protokołów jak i mediów transmisyjnych zrodzilo problem czasu potrzebnego na ponowne zestawianie tuneli pomiędzy zainteresowanymi lokalizacjami w przypadku zerwania jednej ze ścieżek. $W$ artykule przedstawiono porównanie niezawodności różnorodnych tuneli opartych na protokole IP (Internet Protocol) implementowanych na urzadzeniach sieciowych o zastosowaniu militarnym.

Stowa kluczowe: niezawodność, protokót IP, tunelowanie 
Reliability of IP tunnels in military networks

Niezawodność tuneli IP $w$ sieciach militarnych

\section{Introduction}

Is nothing new, that the development of the latest technology has always been driven by the arms race. Military technologies coming out of use in the military were on the civilian market, which allowed for the modernization of society. One of the areas which the rapid development occurred with the needs of troops is telecommunication networks. In both military and commercial networks have always been the most important loss of data and associated delays $[6,7,8]$. Therefore, it was decided to examine the influence of various factors, both environmental $[9,10,11]$ and configuration on the amount of lost data in virtual tunnels.[1,2]

\section{Characteristics of the military network}

Today's military network on the basis of the draft are extensive military network MILNET (Military NETwork), founded in 1984.in the United States as part of the network ARPANET - the beginning of the Internet. With the development of networks and dissemination of modern applications outside of the US, other countries also have developed equivalent MILNET. In military this is the role of the MIL-WAN. Military networks differ from their civilian counterparts on many levels. Oh, the main feature is the requirement for the highest possible level of security for data transmission. Orders, intelligence and other sensitive data that should not get into the wrong hands should be protected in a special way. This is used for external device encryption (PCI PTS) or encrypting routers outbound traffic. The second most important parameter required from military networks is their reliability. For this purpose apply connection redundancy between different locations using different transmission media. Typically uses the following links:

- fiber optic,

- one-pair wire (PKL),

- copper(Ethernet),

- wireless - both radio links with high throughput and radio stations with a omnidirectional range.

The following diagram shows an example of telecommunication network of the military with the redundant paths between different locations. Each of the above mentioned communication media have distinctive characteristics that determine their use. Radio stations are used in the initial phase of dealing with posts by combat units, when there is not yet a developed infrastructure [3]. That way, when you develop the cable unit already has an initial connectivity. Radio stations-based network is a network of MANET (Mobile Ad-hoc NETwork-mobile ad-hoc network). Devices of this type allow for data transmission even in the case of units that are on the move (with a relatively low speed).From the point of view of reliability, the military uses, usually with cable connections, those are not dependent on the weather conditions and terrain. Therefore, use the connection of copper and fiber. When there was still a fiber optics, cables, copper was used as the main medium for transmission. 
With the introduction of optical infrastructure, copper has fallen by the wayside as a kind of backup. This was due to both higher throughputs offered by the optical fiber and the lack of radiate the signal out through optical cables, which reduced the possibility of tapping and increased safety. Radio links are used in areas where the distance between the units prevented the placement of wiring. Switching times from the damaged tracks on up are different and depend on the used hardware and protocols. In the General case, when data transmission is not encrypted, the number of lost packets is close to zero and adds virtually no losses. However, with the military point of view, the most important is the reliability of secure data transmission using equipment and encryption algorithms.

To secure military networks apply IP tunnels. In the case of external encryption devices use traffic (GRE, Generic Routing Encapsulation). Collate it unencrypted tunnels between routers, which add additional IP addresses to packages by not passing. The second case is the use of routers that encrypt traffic using IPsec tunnels (Internet Protocol security) [4]. Working in the tunnel mode creates a virtual security link data and information about the sender and the receiver. The third way is a combination of IPsec tunnels GRE. As a result, we get a secure network to move packages in a one-to-many relationship (multicast traffic) [5].

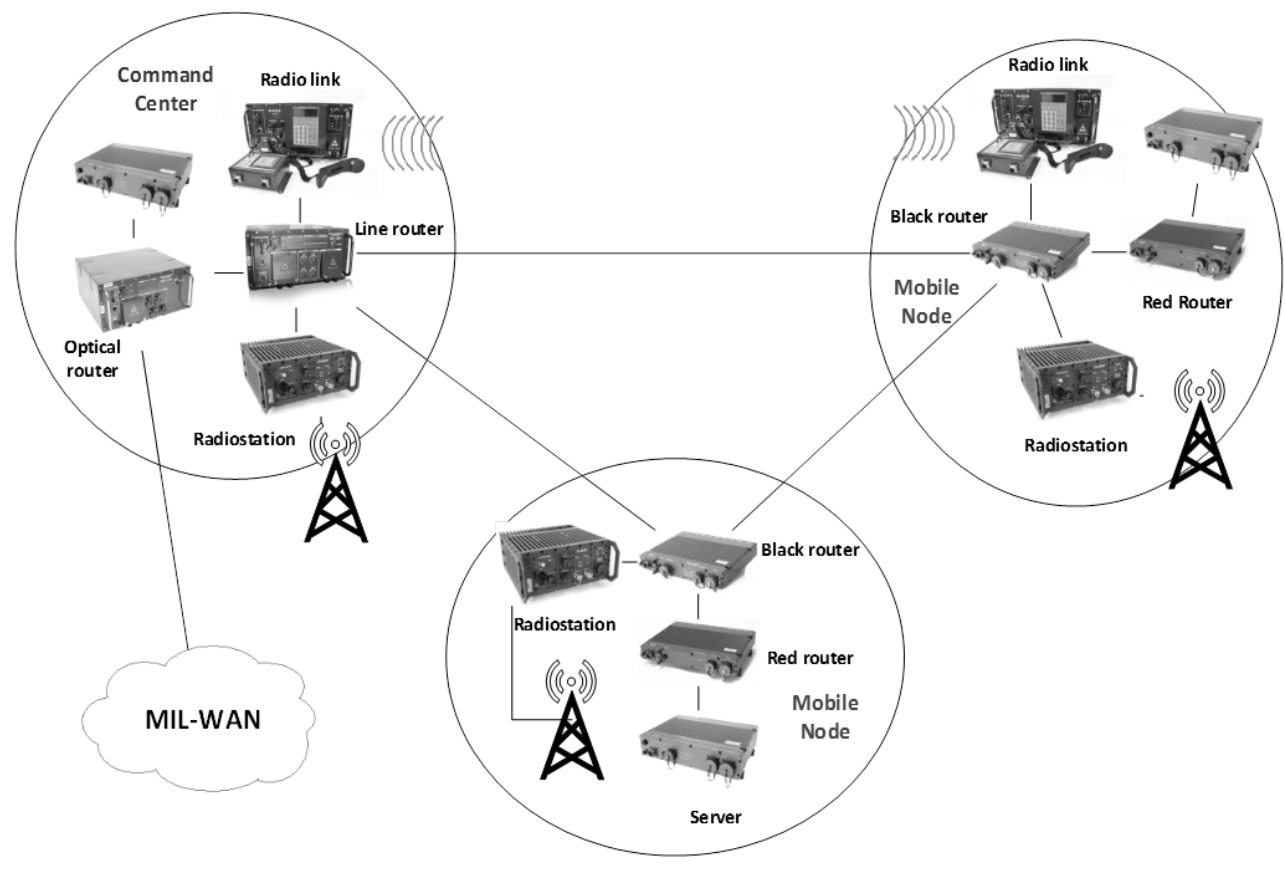

Fig. 1. Diagram of a sample network with redundancy military connections 
Reliability of IP tunnels in military networks

Niezawodność tuneli IP $w$ sieciach militarnych

\section{Research scheme}

The main purpose of the study was the analysis of the configuration of network devices, to ensure the highest reliability of connections using IP tunnels. The classic definition of reliability is based on a designation function reliability of determining time to work properly. From the point of view of the whole ICT network as a single service provider object has been adopted as a criterion for determining the reliability of the number of packets lost during the work in a variable environment. In practice, this means the dependence of the amount of lost data when you change the availability of connections between the nodes of a communications van or base. In this situation, the ICT network readiness index is specified, the following relationship:

$$
K=1-\frac{\text { losed data }[k B]}{\text { transmitted data }[k B]}
$$

The study has been done in a test environment consisting of military equipment used commonly in units of Army.

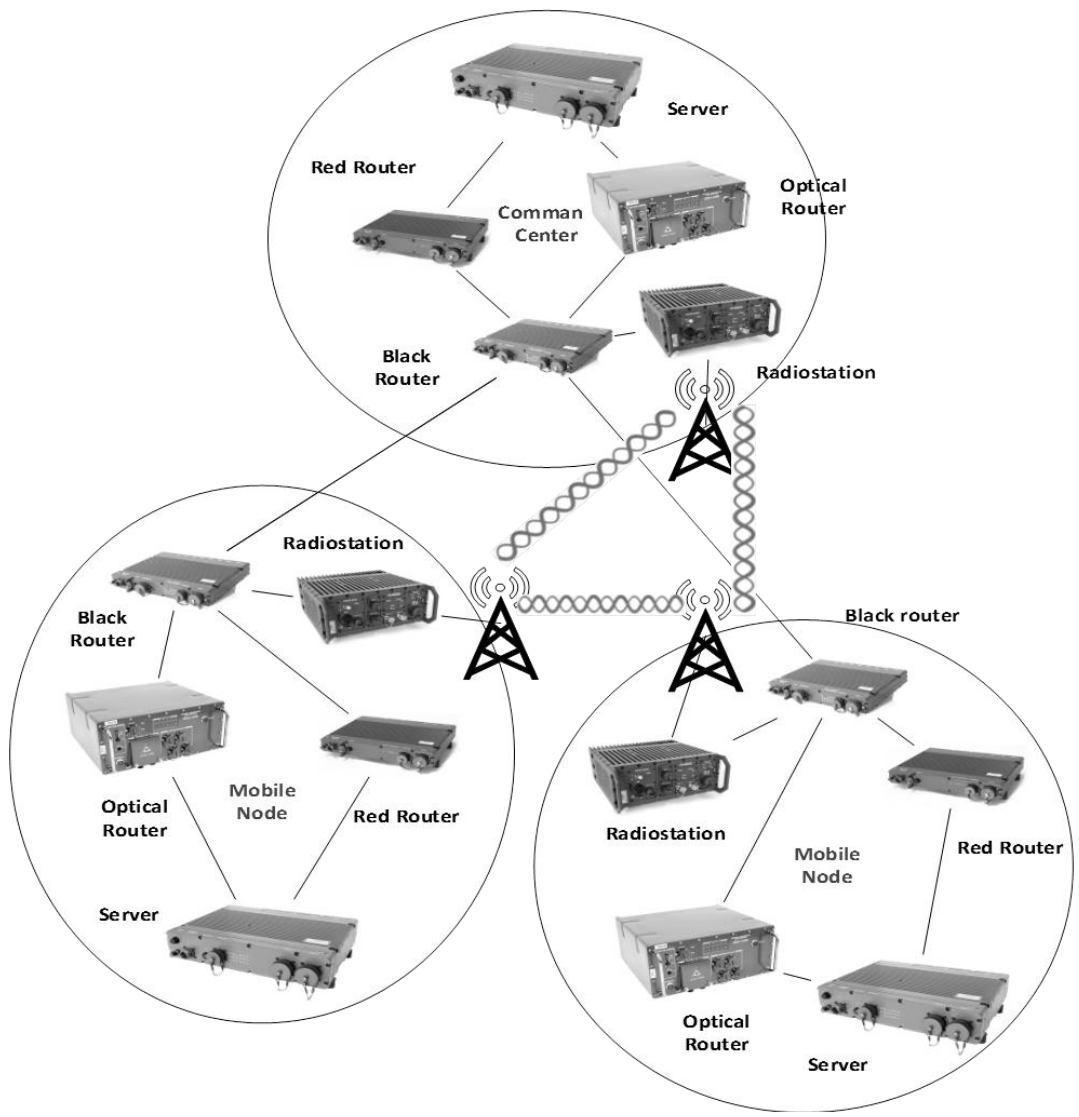

Fig. 2. Scheme of test-bed 
The most important feature of equipment authorized for use in military terms is its resistance to adverse conditions. The main problem in the case of network solutions becomes breaking connections, for example: by the cable break or jam/distortion of the wireless station. Therefore, the study has focused on checking how they fared against establishing a secure connection by changing the medium of broadcasting. The skeleton of the network is based on the devices the RP-XX0. These are devices that support different type of protocols used in the construction of wide area networks (WAN, Wide Area Network) and local (LAN, Local Area Network). RP-XX0 with mobile communication nodes are directly connected with the node command with the help of two different transmission media: single mode fiber with a maximum bandwidth of $34 \mathrm{MB} / \mathrm{sec}$ and PKL cable $1 \times 2$ on SHDSL TRANSMISSION with a maximum bandwidth $2 \mathrm{MB} / \mathrm{s}$. Additionally, have the radio using radio station R-450 c-speed to $34 \mathrm{MB} / \mathrm{s}$ (depending on the prevailing weather conditions and the distance between the radio stations). The study consisted of generating network traffic throughput of $30 \mathrm{MB} / \mathrm{s}$, by one of the three options for the tunnel IP: GRE, IPsec, GRE + IPsec. The throughput generated traffic was chosen so that it was close to the maximum network bandwidth. For the duration of the traffic generation, which was $20 \mathrm{~min}$, simulates a 100 damage to the connections between locations, in such a way as to force the switching of traffic on a different path. These tests are divided into two parts. The first of these consisted of routing packets on all routers using the OSPFv3, and the second consisted in the introduction of static routing on the SHDSL path - which is usually used as a last resort, and optical-that is the fastest. On the one hand, the static routes have the lowest cost, but for OSPF also count the bandwidth of the link. Files used by traffic from servers acting as workstations. Tunneling packets is done using the router software and hardware router.

\section{Results}

GRE tunnels and traffic by not passed has been used as a link to the encrypted tunnels. GAME tunnel does not introduce any losses to the transmission. It is caused by a small mark-up data by heading the GAME added to the IP packet. In order to preserve the transparency of data does not provide them on the first two charts. Charts showing the test results are below.

By comparing the received data, you can see that encrypted tunnels introduce loss frames that were caused by loss of data integrity by fragmented packets that do not fit in the maximum size of frames. Because the files used by TCP protocol traffic, all the incorrect frame has been removed and reported requests for retransmissions. In connection with what there was a momentary moment slowing down of transmitted packets. 
Reliability of IP tunnels in military networks

Niezawodność tuneli IP $w$ sieciach militarnych

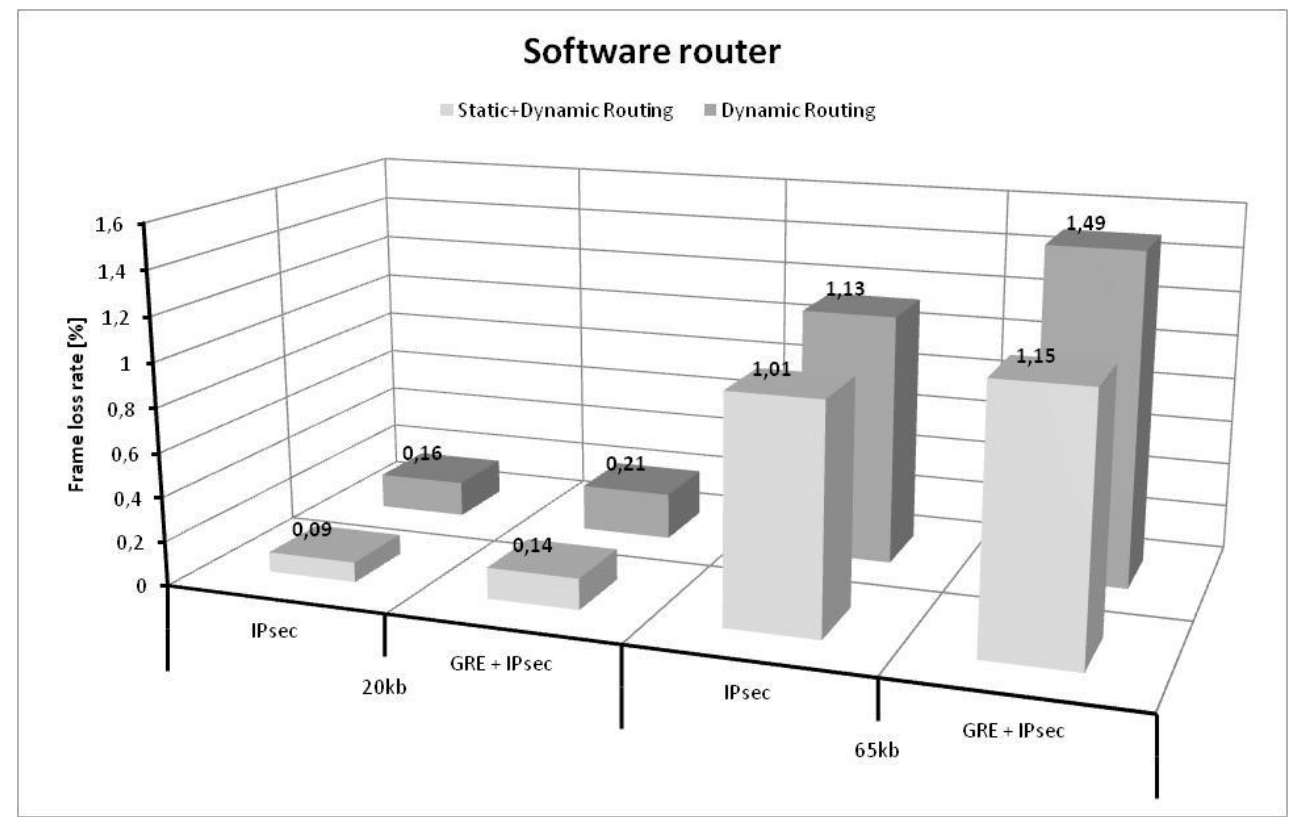

Fig. 3. The number of lost frames for software router

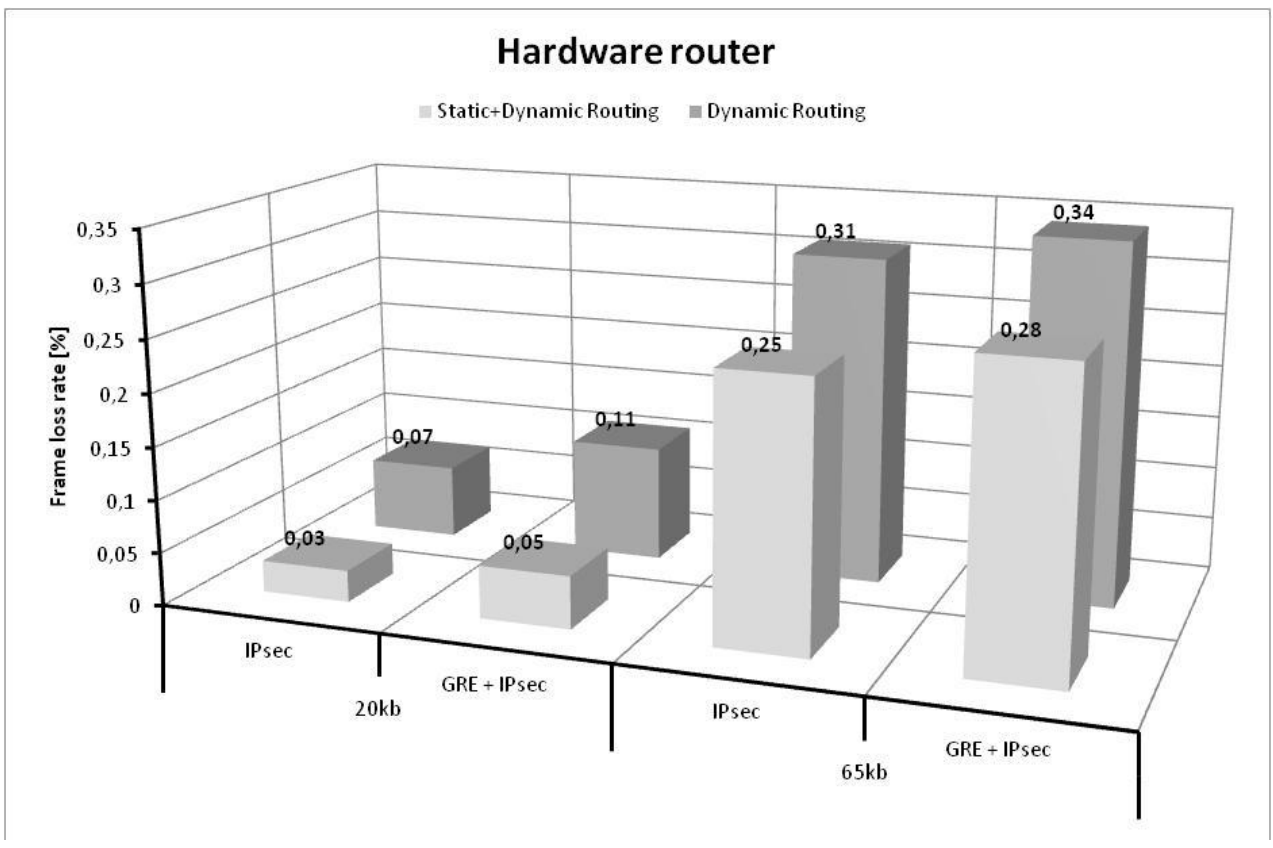

Fig. 4. The number of lost frames for a hardware router 
The combination of IPsec tunnels and increased the number of lost data, because data encryption using hardware resources is substantially increased and the addition of the GRE header had already had a negative impact on the performance of routers. The difference between the numbers of lost frames in both devices was caused by the performance of both routers. Because the router routes traffic software packages by using the software, shall be debited to the same processor, by what remains of fewer resources to encrypt the data. Adding a static route has reduced significantly the amount of lost data because the returns to the previously failed static paths occur faster than routed paths dynamically. Figures 5 and 6 show the network readiness index charts built from data routers as a function of the size of the IP packet.

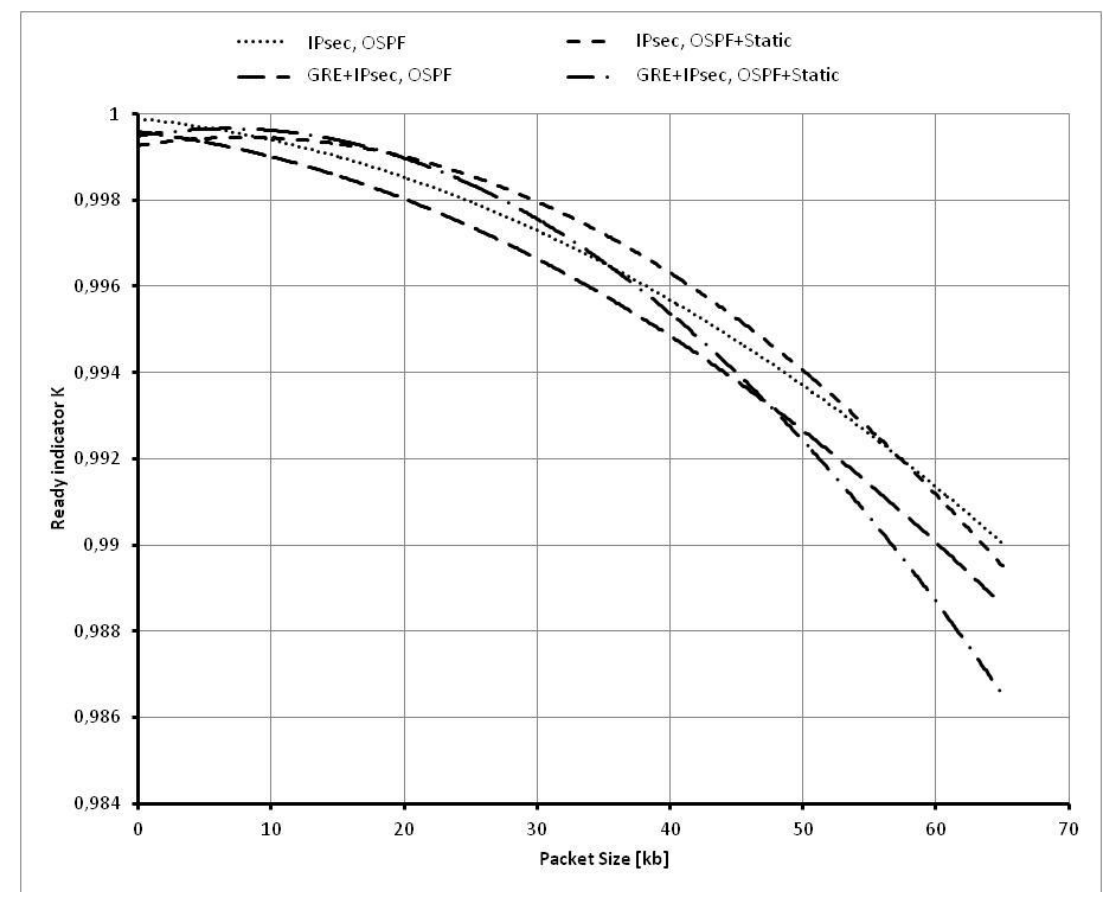

Fig. 5. Software router

Charts are the value approximated using polynomial regression of second degree. With this clearly presents trends K-factor.

Increase in the volume of packets caused more and more damage, which was caused by the large amount of data to be treated at once encryption. With such heavy traffic router software clearly set reliability of transmitted packets from the router. 
Reliability of IP tunnels in military networks Niezawodność tuneli IP $w$ sieciach militarnych

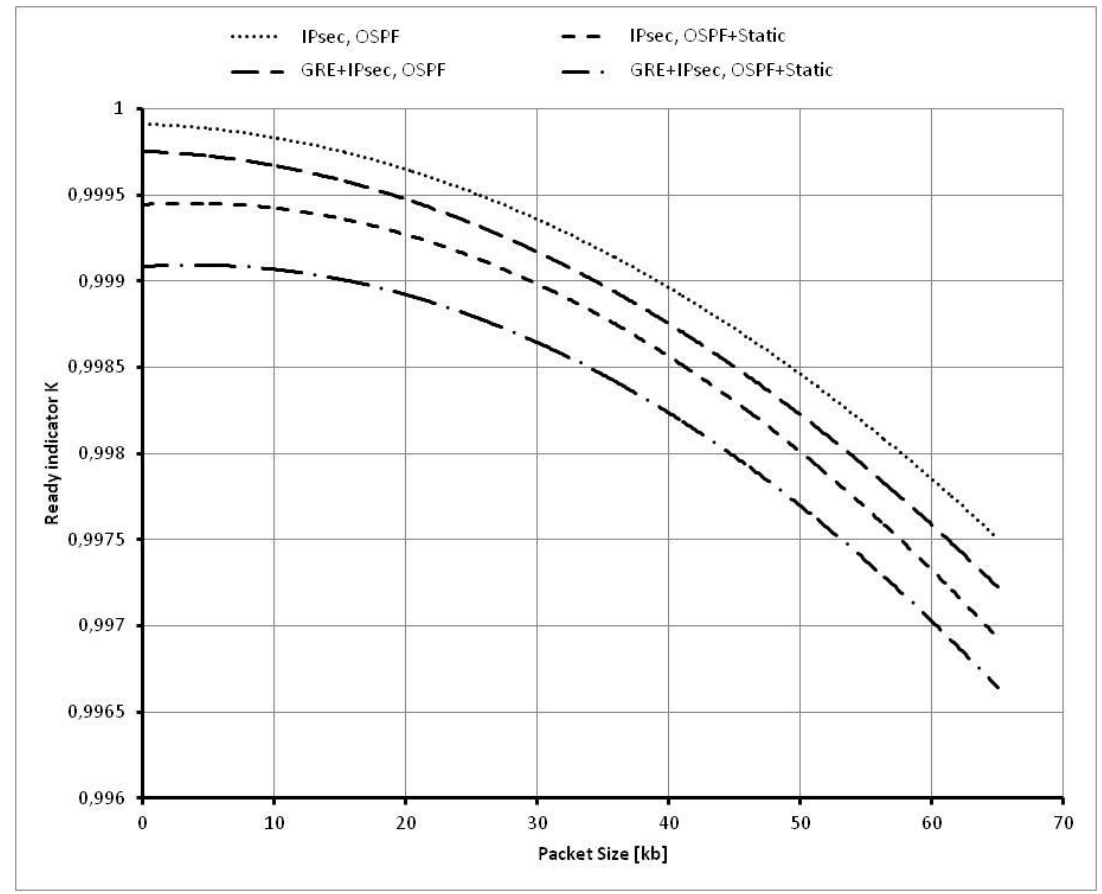

Fig. 6. Hardware router

\section{Conclusions}

Modern commercial networks and the Internet are derived from the first military network. Both technological groups are struggling with the same problems-the loss of data and associated delays. However, the nature of parameters affecting these attributes is different and that is caused by diverse factors, which do not exist in the public wide area networks. Therefore, devices, ICT have a different construction than those sold commercially and hence their configuration, although based on the same standards, is different. All this to use your resources to the maximum with the best effect.

The article was intended to differentiate between public networks and military and ways to deal with difficult military network conditions. By analyzing the results of research, you may notice that the use of hardware-based routers, which are more expensive than software routers, it is not always necessary. With broadcast packets with the relatively small size of the differences in the number of lost frames were not that significant. The percentage shown in the number of lost data differ from those available on the everyday even during military exercises, because in normal circumstances, even the number of combat damage data paths does not reach such a value like this during the test. The purpose of this procedure was to bring out the differences in the use of static routes on some tracks. 
Marcin Pólkowski, Dariusz Laskowski

\section{References}

[1] Pólkowski M., Laskowski D.: Analysis of MPLS VPN resistance to external threats, Safety and Reliability Systems, Publishing and printing House of the Air Forces Institute of Technologies, Poland, Journal of KONBiN No 3(35) 2015, pp. 63-72, ISSN 1895-8281, DOI: 10.1515/jok-2015-039.

[2] Laskowski D., Byłak M.: Diagnosis coding efficiency of network coding mechanism for wireless networks, Electrical Review, R. 89 9/2013, SigmaNot, Warsaw, 2013, pp. 133-138, ISSN 0033-2097.

[3] Laskowski D., Łubkowski P, M. Kwasniewski: Identification of suitability services for wireless networks, Electrical Review, R. 89 9/2013, Sigma-Not, Warsaw, 2013, pp. 128-132, ISSN 0033-2097.

[4] Pólkowski M., Laskowski D., Lubkowski P.: Application of data encryption for building modern virtual private networks, Theory and Engineering of Complex Systems and Dependability, Springer International Publishing AG, Switzerland, Volume 365, 2015, pp. 403-412, ISSN 2194-5357, ISBN 978-3319-07012-4 (Print), DOI 10.1007/978-3-319-07013-1_31.

[5] Lubkowski P., Laskowski D.: Test of the multimedia services implementation in in-formation and communication networks, Advances in Intelligent Systems and Computing, Springer International Publishing AG, Switzerland, Volume 286, 2014, pp 325-332, ISSN 2194-5357, ISBN 978-3-319-07012-4 (Print) 978-3-319-07013-1 (Online), DOI 10.1007/978-3-319-07013-1_31.

[6] Siergiejczyk M., Krzykowska K., Rosiński A.: Parameters analysis of satellite support system in air navigation, Advances in intelligent systems and computing, Springer International Publishing AG, Switzerland, Volume 1089, 2015, pp. 673-678.

[7] Siergiejczyk M., Krzykowska K., Rosiński A.: Reliability assessment of cooperation and replacement of surveillance systems in air traffic, Advances in intelligent systems and computing, Springer International Publishing AG, Switzerland, Volume 286, 2014, pp. 403-411.

[8] Siergiejczyk M., Krzykowska K., Rosiński A.: Reliability assessment of integrated airport surface surveillance system, Advances in intelligent systems and computing, Springer International Publishing AG, Switzerland, Volume 365, 2015, pp. 435-443.

[9] Siergiejczyk M., Paś J., Rosiński A.: Evaluation of safety of highway CCTV system's maintenance process. Communications in Computer and Information Science, Springer International Publishing AG, Switzerland, Volume 471, 2014, pp. 69-79. 
Reliability of IP tunnels in military networks

Niezawodność tuneli IP $w$ sieciach militarnych

[10] Choromański W., Dyduch J., Paś J.: „Minimizing the Impact of Electromagnetic Interference Affecting the Control System of Personal Rapid Transit in the Context of the Competitiveness of the Supply Chain" Archives Of Transport, Polish Academy of Sciences Index 201 901, Volume 23, Issue 2, 2011, pp. 137-152, ISSN 0866-9546.

[11] Paś J.: Selected methods for increases reliability the of electronic systems security, Journal of KONBiN 3(35)2015, pp. 147-156, DOI 10.1515/jok-2015047.

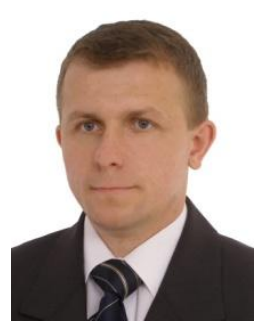

Dariusz Laskowski DSc. Eng. graduated from the Faculty of Electronics, Military University of Technology, where he now works. He is a multi-faceted analysis of the phenomena determining the correct implementation of services in heterogeneous systems and networks offering data transmission. The focus is on reliability, safety, quality and survival of technical objects in terms of their practical use in heterogeneous networks (Share 50\%).

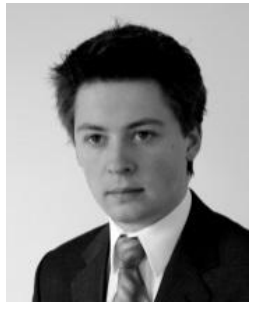

Marcin Pólkowski is employed in the Transbit company the position of specialist Networks in 2014. He graduated from the Faculty of Electronics, Military University of Technology. It deals with the analysis of the phenomena occurring during the routing of data in complex structures of the system using modern and perspective techniques and technologies in ICT networks (Share 50\%). 


\section{NIEZAWODNOŚĆ TUNELI IP W SIECIACH MILITARNYCH}

\section{Wstęp}

Nie jest niczym nowym fakt, że rozwój najnowszych technologii od zawsze był napędzany przez wyścig zbrojeń. Technologie militarne wychodząc z użytku w wojsku wchodziły na rynek cywilny, co pozwalało na unowocześnianie życia społeczeństwa. Jednym z obszarów, którego gwałtowne rozwinięcie nastąpiło dzięki potrzebom wojska są sieci teleinformatyczne.

Zarówno w wojskowych jak i komercyjnych sieciach od zawsze najważniejsze były straty danych oraz związane z nimi opóźnienia. Dlatego postanowiono zbadać wpływy różnych czynników, zarówno konfiguracyjnych jak i środowiskowych na ilość traconych danych w wirtualnych tunelach danych.[1,2]

\section{Charakterystyka sieci militarnych}

Współczesne wojskowe rozległe sieci teleinformatyczne bazują na podstawie projektu militarnej sieci MILNET (ang. MILitary NETwork), powstałym w 1984r. w Stanach Zjednoczonych jako części sieci ARPANET - zaczątku sieci Internet. $\mathrm{W}$ raz z rozwojem sieci i rozpowszechnianiem się nowoczesnych zastosowań poza Stanami Zjednoczonymi, inne kraje również opracowały swoje odpowiedniki MILNET-u. W Polsce tę rolę pełni MIL-WAN.

Sieci militarne różnią się od swoich cywilnych odpowiedników na wielu płaszczyznach. Och główną cechą jest wymaganie najwyższego możliwego poziomu bezpieczeństwa dla przesyłanych danych. Rozkazy, dane wywiadowcze oraz inne poufne dane, które nie powinny się dostać w niepowołane ręce powinny być chronione $\mathrm{w}$ szczególny sposób. Zapewnia się to poprzez szyfrowanie transmisji, zarówno na poziomie pakietów IP jak i niższych warstw modelu OSI (np. standardy TRANSEC oraz COMSEC $w$ transmisjach radiowych). W tym celu stosuje się zewnętrzne urządzenia szyfrujące (tzw. szyfratory) lub routery szyfrujące wychodzący ruch.

Drugim najważniejszym parametrem wymaganym od sieci wojskowych jest ich niezawodność. Do tego celu stosuje się redundancję połączeń pomiędzy różnymi lokalizacjami przy pomocy różnych mediów transmisyjnych. Zazwyczaj wykorzystuje się następujące łącza:

- światłowodowe;

- przewodowe jednoparowe - przy użyciu kabla PKL 1x2;

- miedziane typu Ethernet;

- radiowe - zarówno radioliniowe o wysokich przepustowościach jak i radiostacje o zasięgu dookólnym.

Poniższy schemat przedstawia przykładową teleinformatyczną sieć militarną $\mathrm{z}$ redundantnymi ścieżkami pomiędzy odrębnymi lokalizacjami. 


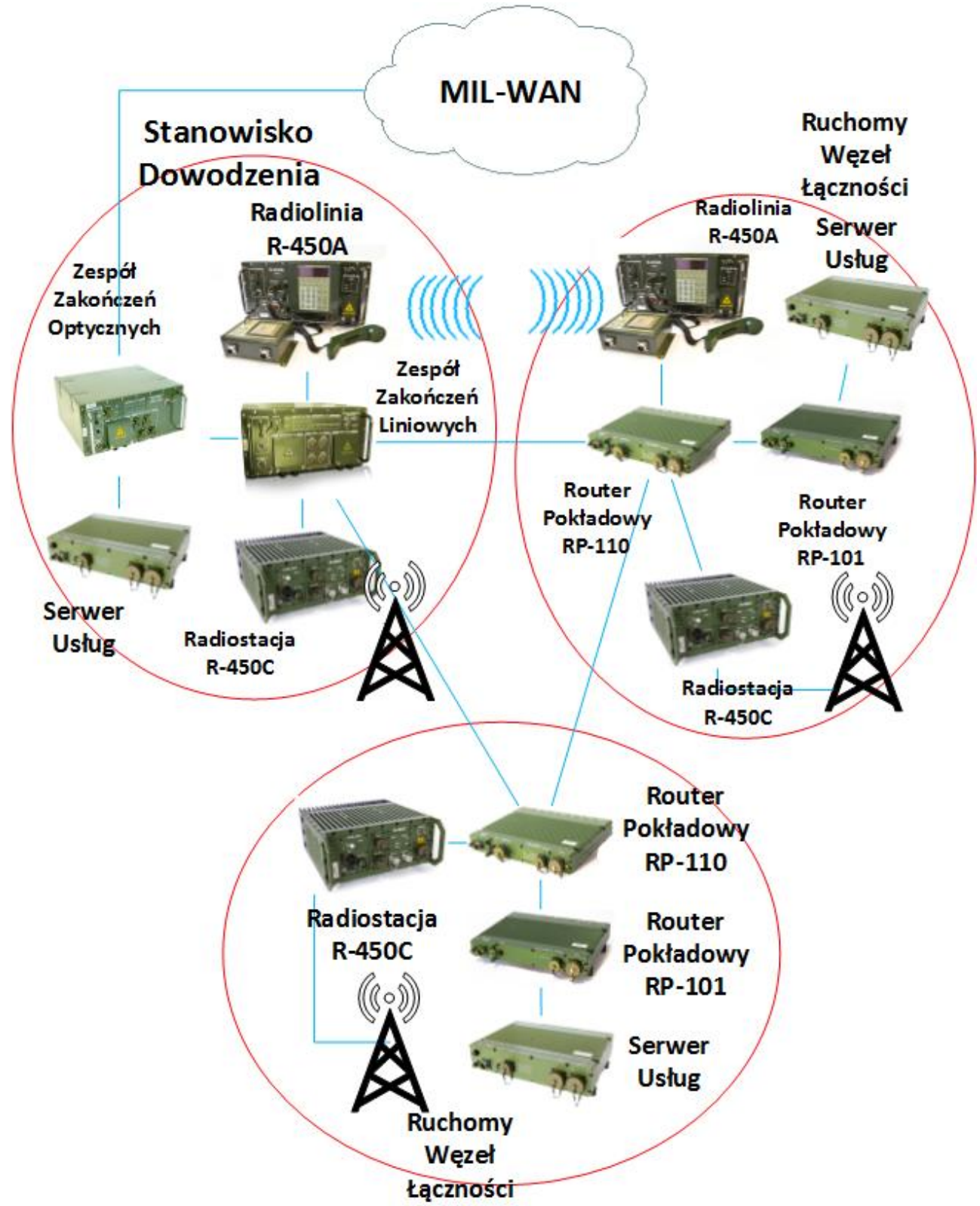

Rys. 3. Schemat przykładowej sieci militarnej z redundancja połaczeń.

Każde z wyżej wymienionych mediów transmisyjnych posiada charakterystyczne cechy, które determinują ich zastosowania. Radiostacji używa się w początkowej fazie zajmowania stanowisk przez jednostki bojowe, kiedy nie ma jeszcze rozwiniętej infrastruktury kablowej. [3] Dzięki temu podczas rozwijania kabli jednostki mają już wstępną łączność. Sieć oparta na radiostacjach jest siecią 
MANET (ang. Mobile Ad-hoc NETwork - mobilna sieć ad-hoc). Urządzenia tego typu pozwalają na transmisje danych nawet $\mathrm{w}$ przypadku jednostek będących w ruchu (o stosunkowo małej prędkości).

$\mathrm{Z}$ punktu widzenia niezawodności, wojsko korzysta zazwyczaj $\mathrm{z}$ połączeń kablowych, które nie są zależne od warunków atmosferycznych i ukształtowania terenu. Dlatego wykorzystuje się połączenia miedziane i światłowodowe. Gdy nie było jeszcze światłowodów, okablowanie miedziane było wykorzystywane jako główne medium transmisyjne. Wraz z wprowadzeniem infrastruktury optycznej, miedź spadała na dalszy plan jako swoisty backup. Spowodowane było to zarówno większymi przepustowościami oferowanymi przez światłowodu jak i brakiem wypromieniowywania sygnału na zewnątrz kabli optycznych, co ograniczało możliwości podsłuchu i zwiększało bezpieczeństwo.

Łącza radioliniowe znalazły zastosowanie w miejscach, gdzie odległości pomiędzy jednostkami uniemożliwiały położenie okablowania.

Czasy przełączania z uszkodzonej ścieżki na zapasową są różne i zależą od użytego sprzętu i wykorzystywanych protokołów. W ogólnym przypadku, gdy transmisja danych nie jest szyfrowana, liczba utraconych pakietów jest bliska zeru i nie wnosi praktycznie żadnych strat. Jednak z militarnego punktu widzenia najważniejsza jest niezawodność zabezpieczonej transmisji danych przy pomocy urządzeń i algorytmów szyfrujących.

Do zabezpieczania sieci militarnych stosuje się tunele IP. W przypadku zewnętrznych urządzeń szyfrujących ruch używa się protokołu GRE (z ang. Generic Routing Encapsulation). Zestawia on nieszyfrowane tunele pomiędzy routerami końcowymi, które dodają dodatkowe adresy IP do pakietów przez nie przechodzących.

Drugim przypadkiem jest zastosowanie routerów, które szyfrują ruch przy pomocy tuneli IPsec (z ang. Internet Protocol security).[4] Pracując w trybie tunelowym tworzy wirtualne łącze zabezpieczające przesyłane dane jak i informacje o nadawcy i odbiorcy.

Trzeci sposób jest kombinacją protokołu IPsec $\mathrm{z}$ tunelami GRE. W rezultacie dostajemy bezpieczną sieć umożliwiającą ruch pakietów w relacjach jeden do wielu (z ang. multicast traffic).[5]

\section{Schemat badań}

Głównym celem badań była analiza możliwości konfiguracji urządzeń sieciowych, mających zapewnić jak najwyższą niezawodność połączeń realizowanych przy pomocy tuneli IP.

Klasyczna definicja niezawodności opiera się na wyznaczeniu funkcji niezawodności określającej czas poprawnej pracy danego obiektu. Z punktu widzenia całości sieci teleinformatycznej jako pojedynczego obiektu świadczącego określone usługi przyjęto jako kryterium określania niezawodności ilość utraconych pakietów podczas pracy $\mathrm{w}$ zmiennym środowisku. 
Reliability of IP tunnels in military networks

Niezawodność tuneli IP $w$ sieciach militarnych

W praktyce oznacza to zależność ilości utraconych danych podczas zmieniania się dostępności połączeń pomiędzy węzłami łączności a wozem lub bazą dowodzenia. W takiej sytuacji określono wskaźnik gotowości sieci teleinformatycznej poniższą zależnością:

$$
K=1-\frac{\text { ilość utraconych danych }[k B]}{\text { ilość przesłanych danycy }[k B]}
$$

Badanie zostały wykonane w środowisku testowym składającym się z urządzeń wojskowych stosowanych powszechnie w jednostkach Wojska Polskiego.

Najważniejszą cechą sprzętu dopuszczonego do wykorzystywania w warunkach militarnych jest jego odporność na niesprzyjające warunki. Głównym problemem w przypadku rozwiązań sieciowych staje się zrywanie połączeń, np. przez przerwanie kabla lub zagłuszenie/zakłócenie stacji bezprzewodowej. Dlatego badania skupiły się na sprawdzaniu jak te urządzenia radziły sobie z nawiązywaniem bezpiecznych połączeń przy zmienianym medium transmisyjnym.

Szkielet sieci oparty jest na urządzeniach RP-110. Są to urządzenia obsługujące różne typu protokołów używanych do budowy sieci rozległych WAN (z ang. Wide Area Network) oraz lokalnych (LAN - z ang. Local Area Network). RP-110 $\mathrm{z}$ ruchomych węzłów łączności są bezpośrednio połączone $\mathrm{z}$ węzłem dowodzenia przy pomocy dwóch różnych mediów transmisyjnych: światłowód jednomodowy o maksymalnej przepustowości $34 \mathrm{Mb} / \mathrm{s}$ oraz kabel PKL 1x2 w systemie SHDSL o maksymalnej przepustowości $2 \mathrm{Mb} / \mathrm{s}$. Dodatkowo mają zapewnioną łączność radiową z wykorzystaniem radiostacji R-450C z maksymalną przepustowością do $34 \mathrm{Mb} / \mathrm{s}$ (zależną od panujących warunków atmosferycznych oraz odległości pomiędzy radiostacjami).

Badania polegały na generowaniu ruchu sieciowego o przepływności $30 \mathrm{Mb} / \mathrm{s}$, przez jedną z trzech opcji tunelu IP: GRE, IPsec, GRE+IPsec. Przepływność generowanego ruchu została dobrana tak aby była bliska maksymalnej przepustowości sieci. W czasie trwania generowania ruchu, który wynosił $20 \mathrm{~min}$, symulowano 100 uszkodzeń połączeń pomiędzy lokalizacjami, w taki sposób aby wymusić przełączenie ruchu na inną ścieżkę. Testy te podzielono na dwie części. Pierwsza $\mathrm{z}$ nich obejmowała trasowanie pakietów na wszystkich routerach przy pomocy protokołu OSPFv3, a druga polegała na wprowadzeniu routingu statycznego na ścieżce SHDSL - która zazwyczaj jest wykorzystana jako ostateczność oraz optycznej - czyli najszybszej. Z jednej strony trasy statyczne mają najniższy koszt, ale dla protokołu OSPF liczy się również przepustowość danego łącza.

Ruch sieciowy generowano z serwerów usług pełniących rolę stacji roboczych. Tunelowanie pakietów odbywało się przy pomocy routera programowego oraz routera sprzętowego. 
Marcin Pólkowski, Dariusz Laskowski

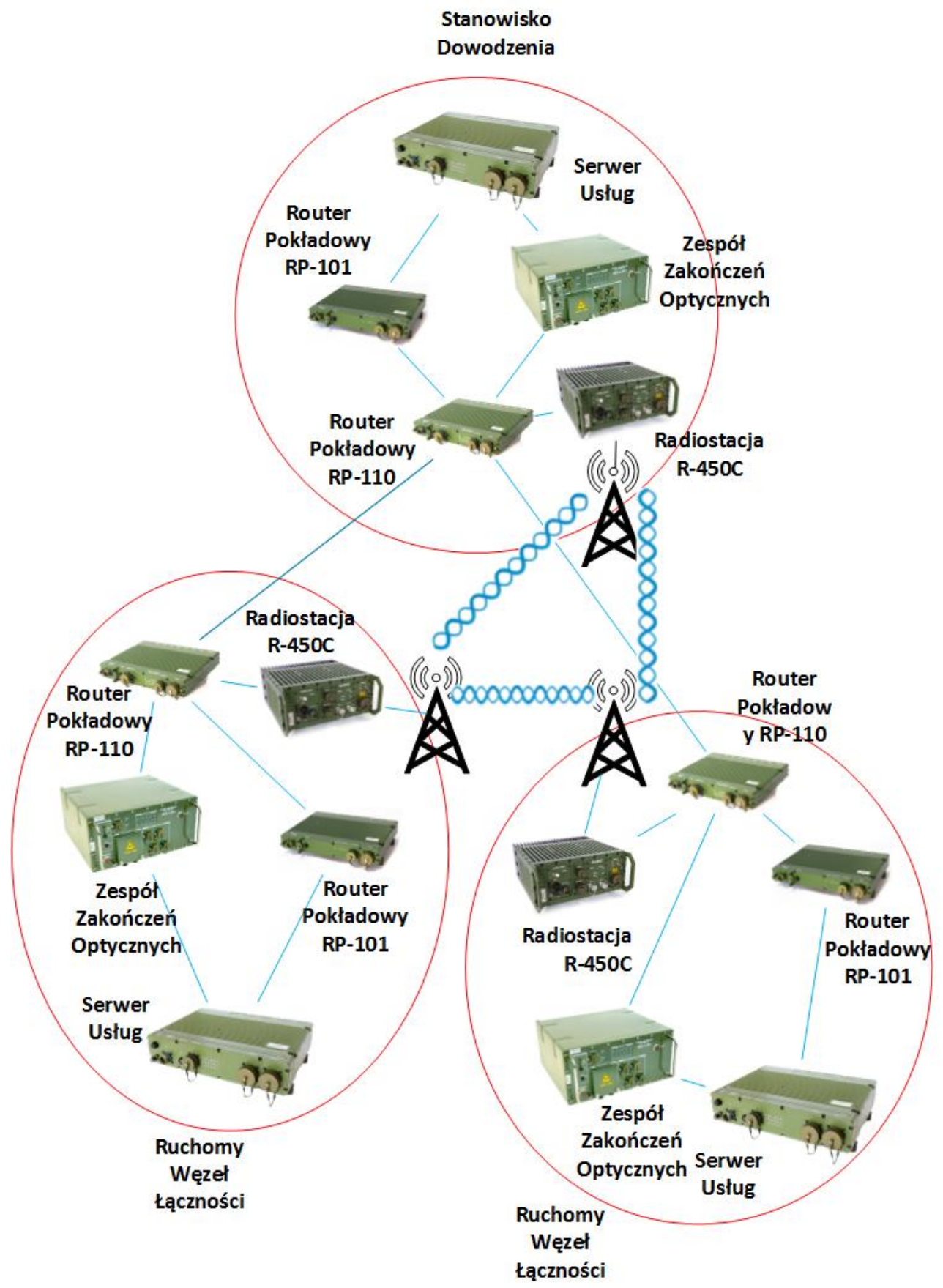

Rys. 4. Schemat środowiska badawczego. 
Reliability of IP tunnels in military networks

Niezawodność tuneli IP $w$ sieciach militarnych

\section{Wyniki}

Wykresy przedstawiające wyniki badań umieszczono poniżej.

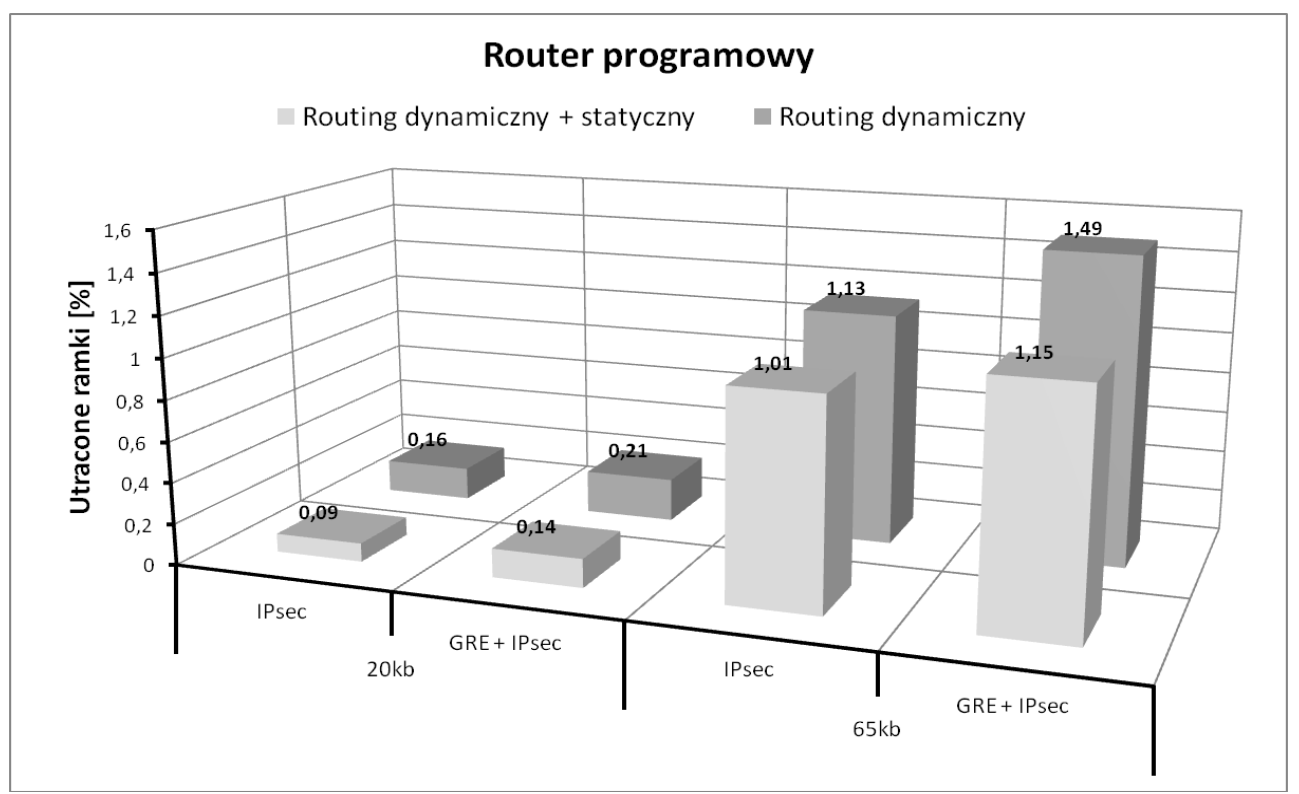

Rys. 3. Liczba utraconych ramek dla routera programowego.

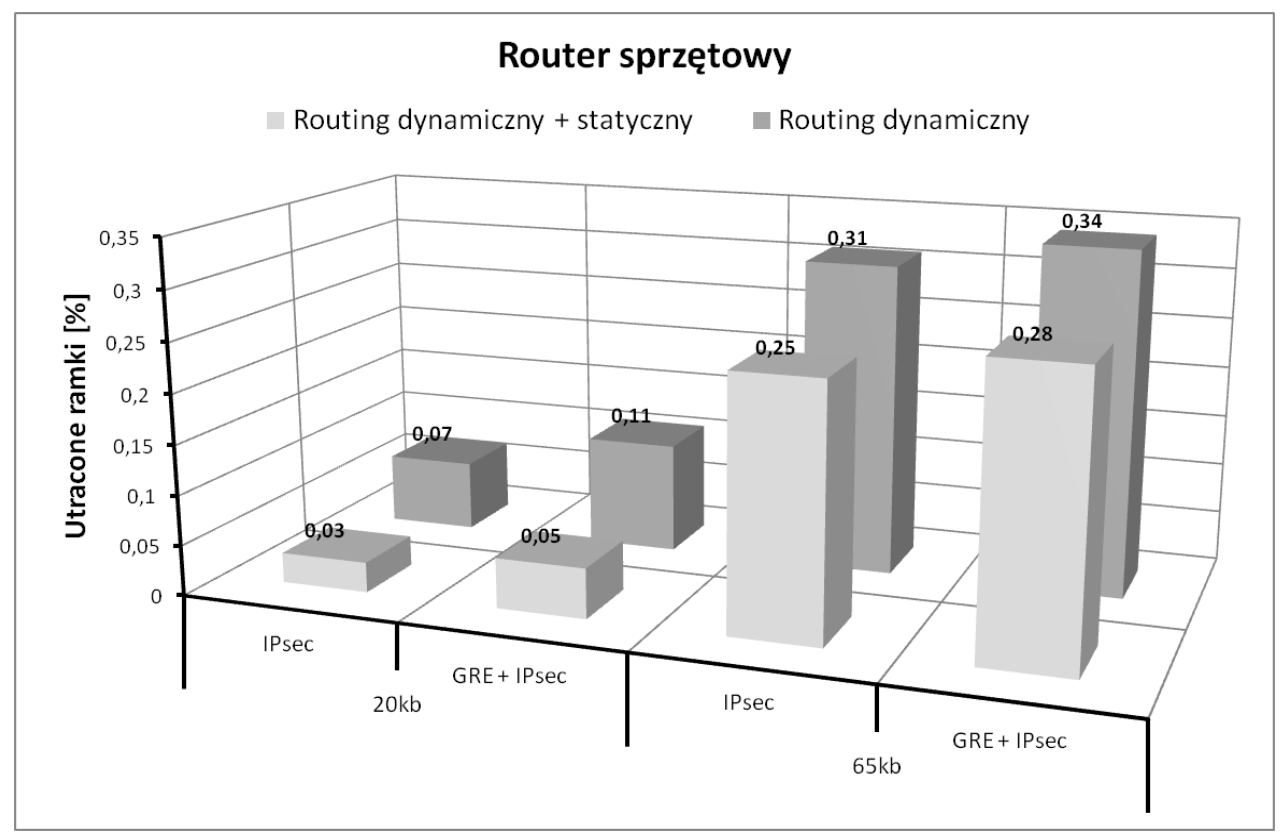

Rys. 4. Liczba utraconych ramek dla routera sprzętowego. 
Tunele GRE i ruch przez nie przepuszczany został wykorzystany jako odnośnik do tuneli szyfrowanych. Tunel GRE nie wprowadza żadnych strat do transmisji. Je to spowodowane małym narzutem danych przez nagłówek GRE dodawany do pakietu IP. Żeby zachować przejrzystość prezentowanych danych nie zamieszczono ich na pierwszych dwóch wykresach.

Porównując otrzymane dane widać, że tunele szyfrowane wprowadzały straty ramek, które spowodowane były utratą integralności danych przez pofragmentowane pakiety, które nie mieściły się w maksymalnej wielkości ramek. Ponieważ generowano ruch $\mathrm{z}$ wykorzystaniem protokołu TCP, wszystkie niepoprawne ramki zostały usunięte $\mathrm{i}$ zgłoszono prośby o retransmisje. $\mathrm{W}$ zawiązku z czym następował chwilowy moment spowolnienia transmitowanych pakietów.

Połączenie tuneli IPsec i GRE zwiększyło liczbę traconych danych, ponieważ podczas szyfrowania danych wykorzystywanie zasobów sprzętowych jest znacznie zwiększone i dodanie nagłówka GRE miało już negatywny wpływ na wydajność routerów.

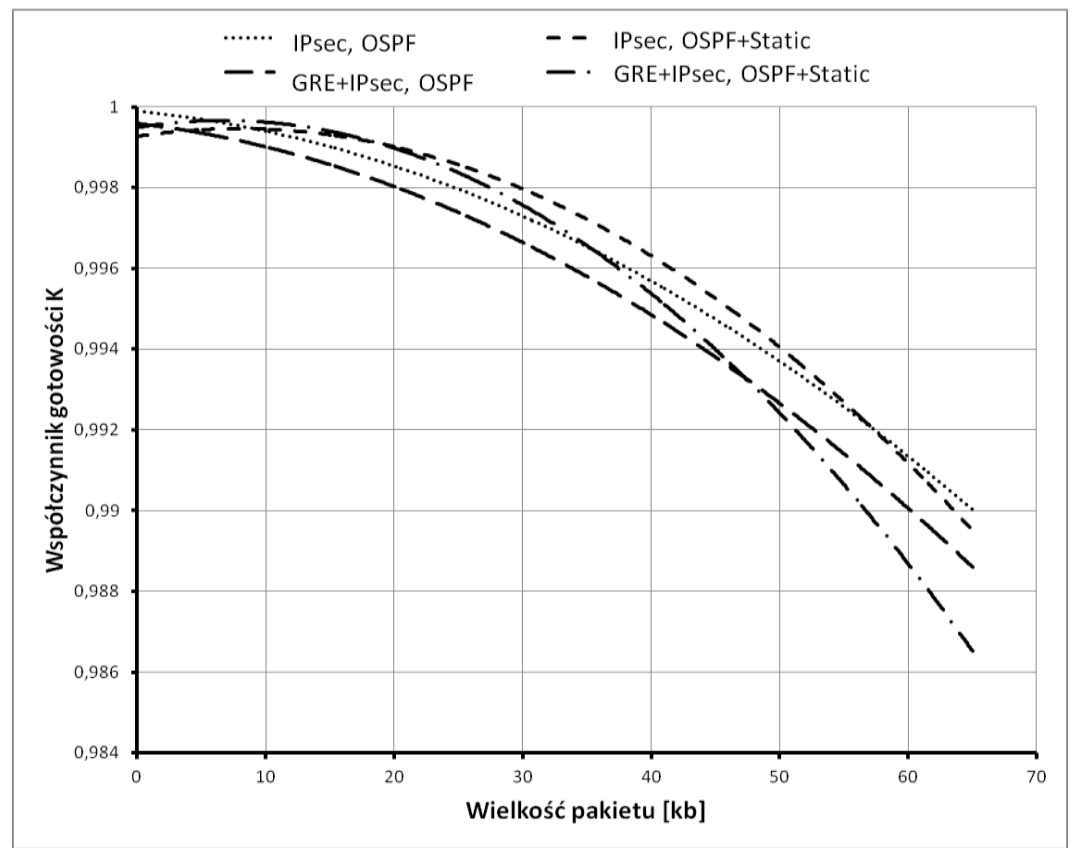

Rys. 5. Router programowy.

Różnica pomiędzy liczbami utraconych ramek w obu urządzeniach była spowodowana wydajnością obu routerów. Ponieważ router programowy trasuje pakiety za pomocą oprogramowania, obciąża tym samym procesor, przez co pozostaje mniej zasobów do szyfrowania danych.

Dodanie trasy statycznej zmniejszyło znacząco ilość traconych danych, ponieważ powroty do uprzednio uszkodzonej ścieżki statycznej następowały szybciej niż w przypadku ścieżek trasowanych dynamicznie. 
Reliability of IP tunnels in military networks

Niezawodność tuneli IP $w$ sieciach militarnych

Rysunki 5 i 6 przedstawiają wykresy wskaźnika gotowości sieci zbudowanej $\mathrm{z}$ danych routerów $\mathrm{w}$ funkcji wielkości pakietu IP. Na wykresach znajdują się wartości aproksymowane przy pomocy regresji wielomianowej drugiego stopnia. Dzięki temu wyraźnie zaprezentowano tendencje zmian współczynnika K.

Wzrost wielkości pakietów powodował coraz większe straty, co było spowodowane dużą ilością danych poddawanych na raz szyfrowaniu. Przy tak dużym natężeniu ruchu router programowy wyraźnie odstawał niezawodnością przesyłanych pakietów od routera sprzętowego.

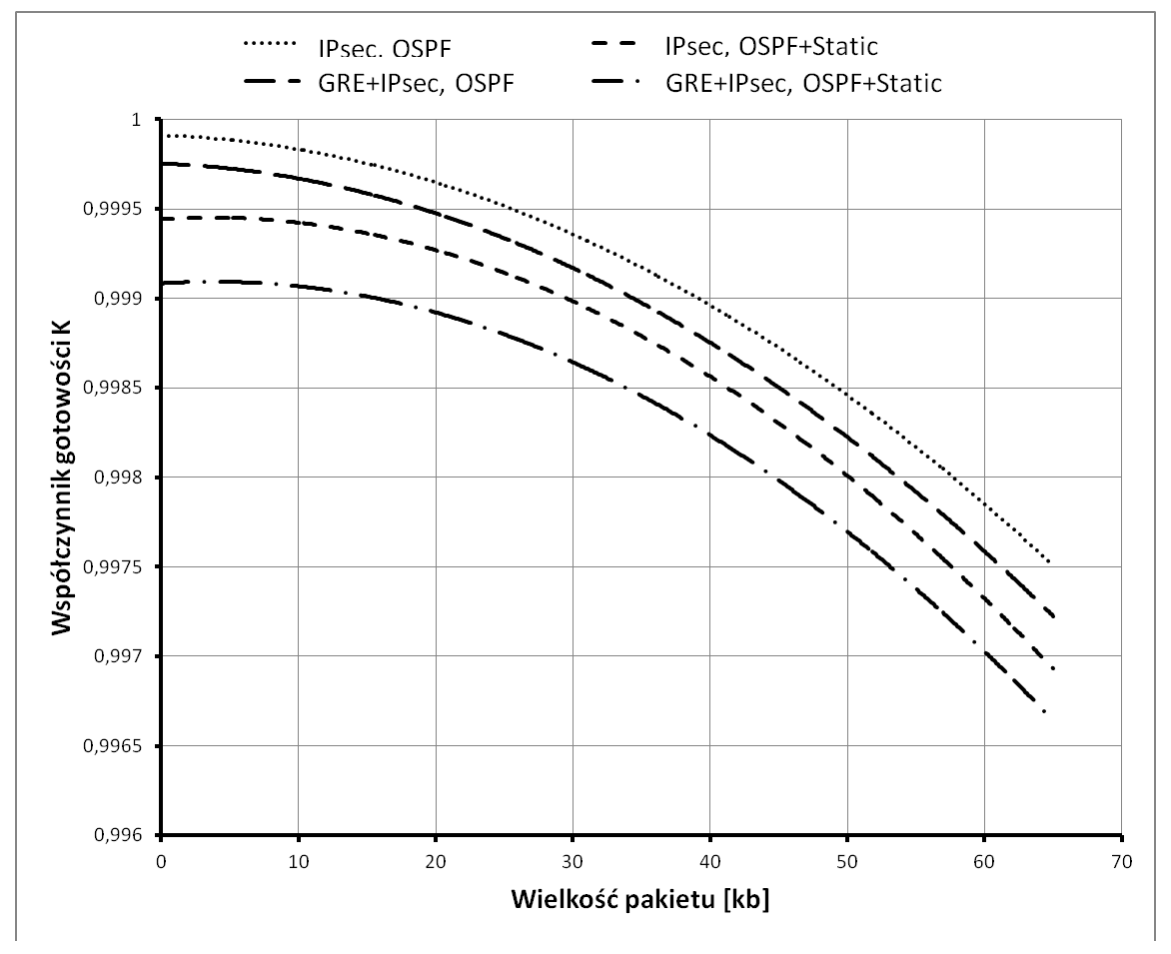

Rys. 6. Router sprzętowy.

\section{Wnioski}

Współczesne sieci komercyjne, jak i cały Internet wywodzą się z pierwszych sieci militarnych. Obie grupy technologiczne borykają się z tymi samymi problemami utratą danych i związanymi z tym opóźnieniami. Jednak charaktery parametrów wpływających na te atrybuty jest inny i powodowany przez zróżnicowany czynniki, które nie występują w publicznych sieciach rozległych. W związku z tym, urządzenia teleinformatyczne mają inną budowę niż te sprzedawane komercyjnie, a co za tym idzie ich konfiguracja, chociaż bazująca na tych samych standardach, jest odmienna. 
Wszystko po to aby wykorzystać dane zasoby do maksimum z jak najlepszym efektem. Artykuł miał na celu pokazanie różnic pomiędzy sieciami publicznymi a militarnymi oraz sposoby radzenia sobie sieci wojskowych $\mathrm{z}$ trudnymi warunkami.

Analizując wynika badań można zauważyć, że stosowanie routerów sprzętowych, które są droższe od routerów programowych, nie zawsze jest konieczne. Przy transmisjach pakietów o stosunkowo małej wielkości różnice w liczbie traconych ramek nie były aż takie znaczące.

Pokazane procentowe liczby traconych danych odbiegają od tych osiągalnych na co dzień nawet podczas ćwiczeń wojskowych, ponieważ w normalnych warunkach, nawet bojowych liczba uszkodzeń danych ścieżek nie osiąga takiej wartości jak ta podczas badania. Celem tego zabiegu było uwypuklenie różnic w stosowaniu tras statycznych na niektórych ścieżkach.

\section{Literatura}

[1] Pólkowski M., Laskowski D.: Analysis of MPLS VPN resistance to external threats, Safety and Reliability Systems, Publishing and printing House of the Air Forces Institute of Technologies, Poland, Journal of KONBiN No 3(35) 2015, pp. 63-72, ISSN 1895-8281, ESSN 2083-4608, DOI: 10.1515/jok-2015-039.

[2] Laskowski D., Byłak M.: Diagnosis coding efficiency of network coding mechanism for wireless networks, Electrical Review, R. 89 9/2013, SigmaNot, Warszawa, 2013r., str. 133-138, ISSN 0033-2097.

[3] Laskowski D., Łubkowski P, M. Kwasniewski: Identification of suitability services for wireless networks, Electrical Review, R. 89 9/2013, Sigma-Not, Warszawa, 2013r., str. 128-132, ISSN 0033-2097.

[4] Pólkowski M., Laskowski D., Lubkowski P.: Application of data encryption for building modern virtual private networks, Theory and Engineering of Complex Systems and Dependability, Springer International Publishing AG, Switzerland, Volume 365, 2015, pp. 403-412, ISSN 2194-5357, ISBN 978-3319-07012-4 (Print), DOI 10.1007/978-3-319-07013-1_31.

[5] Lubkowski P., Laskowski D.: Test of the multimedia services implementation in in-formation and communication networks, Advances in Intelligent Systems and Computing, Springer International Publishing AG, Switzerland, Volume 286, 2014, pp 325-332, ISSN 2194-5357, ISBN 978-3-319-07012-4 (Print) 978-3-319-07013-1(Online), DOI 10.1007/978-3-319-07013-1_31.

[6] Siergiejczyk M., Krzykowska K., Rosiński A.: Parameters analysis of satellite support system in air navigation. In: „Proceedings of the Twenty-Third International Conference on Systems Engineering”, editors: H. Selvaraj, D. Zydek, G. Chmaj, given as the monographic publishing series - „Advances in intelligent systems and computing”, Vol. 1089, pp. 673-678, Springer 2015. 
Reliability of IP tunnels in military networks

Niezawodność tuneli IP $w$ sieciach militarnych

[7] Siergiejczyk M., Krzykowska K., Rosiński A.: Reliability assessment of cooperation and replacement of surveillance systems in air traffic. In: „Proceedings of the Ninth International Conference Dependability and Complex Systems DepCoS-RELCOMEX”, editors: Zamojski W., Mazurkiewicz J., Sugier J., Walkowiak T., Kacprzyk J., given as the monographic publishing series - „Advances in intelligent systems and computing", Vol. 286, pp. 403-411, Springer 2014.

[8] Siergiejczyk M., Krzykowska K., Rosiński A.: Reliability assessment of integrated airport surface surveillance system. In: „Proceedings of the Tenth International Conference on Dependability and Complex Systems DepCoSRELCOMEX”, editors: Zamojski W., Mazurkiewicz J., Sugier J., Walkowiak T., Kacprzyk J., given as the monographic publishing series - „Advances in intelligent systems and computing", Vol. 365, pp. 435-443. Springer, 2015.

[9] Siergiejczyk M., Paś J., Rosiński A.: Evaluation of safety of highway CCTV system's maintenance process. In: the monograph „Telematics - support for transport", editors: Mikulski J., given as the monographic publishing series „Communications in Computer and Information Science”, Vol. 471, pp. 69-79, Springer-Verlag, Berlin Heidelberg 2014.

[10] Choromański W., Dyduch J., Paś J.: „Minimizing the Impact of Electromagnetic Interference Affecting the Control System of Personal Rapid Transit in the Context of the Competitiveness of the Supply Chain" Archives Of Transport, Polish Academy of Sciences Index 201901 ISSN 0866-9546 Volume 23, Issue 2, pp. 137-152, Warsaw 2011.

[11] Paś J.: Selected methods for increases reliability the of electronic systems security, Journal of KONBiN 3(35)2015, str. 147 - 156, DOI 10.1515/jok2015-047.
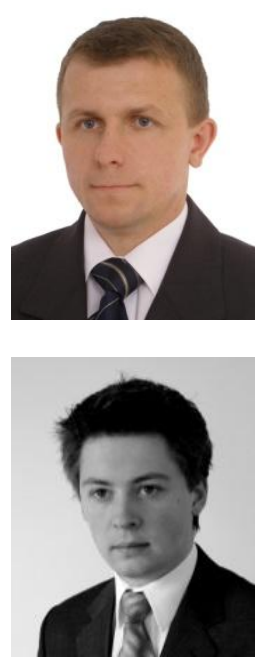

Dr hab. inż. Dariusz Laskowski ukończyt Wydziat Elektroniki Wojskowej Akademii Technicznej, gdzie obecnie pracuje. Zajmuje się wieloaspektowa analiza zjawisk determinujacych poprawność realizacji ustug $w$ heterogenicznych systemach $i$ sieciach oferujacych przesyt danych. Gtówne obszary zainteresowania to niezawodność, bezpieczeństwo, jakość i przeżywalność obiektów technicznych $w$ aspekcie ich praktycznego zastosowania $w$ sieciach heterogenicznych (Udziat 50\%).

Mgr iṅ. Marcin Pólkowski. Ukończyt Wydziat Elektroniki Wojskowej Akademii Technicznej. Obecnie pracuje $w$ firmie Transbit Sp. z o. o. jako specjalista ds. sieci teleinformatycznych (Udziat 50\%). 